\title{
Genetic Polymorphisms and Cancer Susceptibility of Breast Cancer in Korean Women
}

\author{
Daehee Kang* \\ Department of Preventive Medicine, Seoul National University College of Medicine, Seoul 110-799, Korea
}

Received 4 November 2002

\begin{abstract}
Breast cancer is the most prevalent cancer among women in Western countries, and its prevalence is also increasing in Asia. The major risk factor for breast cancer can be traced to reproductive events that influence the lifetime levels of hormones. However, a large percentage of breast cancer cases cannot, be explained by these risk factors. The identification of susceptibility factors that predispose individuals to breast cancer (for instance, if they are exposed to particular environmental agents) could possibly give further insight into the etiology of this malignancy and provide targets for the future development of therapeutics. The most interesting candidate genes include those that mediate a range of functions. These include carcinogen metabolism, DNA repair, steroid hormone metabolism, signal transduction, and cell cycle control. We conducted a hospital-based case-control study in South Korea to evaluate the potential modifying role of the genetic polymorphisms of selected low penetrance genes that are involved in carcinogen metabolisms (i.e., CYP1A1, CYP2E1, GSTM1/T1/P1, NAT1/2, etc.), estrogen synthesis and metabolism (i.e., CYP19, CYP17, CYP1B1, COMT, ER$\alpha$, etc.), DNA repair (i.e., XRCC1/3, ERCC2/4, ATM, AGT, etc.), and signal transduction as well as others (i.e., $T G F-\beta$, $I G F-1, T N F-\beta, I L-1 B, I L-1 R N$, etc.). We also took into account the potential interaction between these and the known risk factors of breast cancer. The results of selected genes will be presented in this mini-review.
\end{abstract}

Keywords: Breast cancer, Case-control study, Genetic polymorphisms, Low penetrance genes

*To whom correspondence should be addressed. Tel: 82-2-740-8326; Fax: 82-2-747-4830

E-mail: dhkang@snu.ac.kr

\section{Introduction}

Breast cancer is the most prevalent cancer among women in Western countries, and its prevalence is also increasing in Asia (Parkin et al., 1997; Yoo et al., 2002). In 1994, the incidence rate of female breast cancer in Korean (adjusted for the world population) was 10.9 per 100,000 , which was far lower than that of Western countries, and even lower than any other Asian country. The major risk factor for breast cancer can be traced to reproductive events that influence the lifetime levels of hormones (Feigelson and Henderson, 1996; Zhu and Conney, 1998).

A large percentage of breast cancer cases cannot, however, be explained by these risk factors. The identification of susceptibility factors that predispose individuals to breast cancer (for example, if they are exposed to particular environmental agents) could possibly give further insight into the etiology of this malignancy. Inherited differences in the capacity to metabolize environmental carcinogens have recently been suggested to modify individual susceptibility to breast cancer. Therefore, the identification of new breast cancer susceptibility genes would yield new insight into breast tumorigenesis, and could provide targets for the future development of therapeutics.

In this respect, the most interesting candidate genes include those that mediate a range of functions. This includes carcinogen metabolism, DNA repair, steroid hormone metabolism, signal transduction, and cell cycle control. Although the relative risks of these low penetrance susceptibility genes to the development of breast cancer are generally lower than those from high penetrance susceptibility genes (e.g., BRCA1, BRCA2, etc.), the population attributable risk of low penetrance genes are much higher than those of the high penetrance gene since the frequency of variant alleles of low penetrance genes are higher in the general population. Therefore, higher public health significance rests on these low penetrance genes with the hope of obtaining more mechanistic insights into human breast carcinogenesis, as well as the targeted-preventive approaches to the individuals with at risk 
Table 1. List of Genes and SNPs analyzed in Korean breast cancer cases and controls

\begin{tabular}{|c|c|c|c|c|}
\hline Group & Gene & SNP & Cases & Controls \\
\hline \multirow{9}{*}{$\begin{array}{l}\text { Xenobiotics } \\
\text { metabolism }\end{array}$} & GSTM1 & deletion & 167 & 176 \\
\hline & GSTT1 & deletion & 168 & 184 \\
\hline & GSTP1 & Ile105Val & 167 & 179 \\
\hline & $N A T 1$ & 11 variants & 277 & 310 \\
\hline & NAT2 & 24 variants & 277 & 310 \\
\hline & $C Y P 2 E 1$ & G-1019C 5'UTR & 329 & 337 \\
\hline & $N Q O 1$ & C609T & 265 & 295 \\
\hline & $E P H X$ & Tyr113His & 149 & 175 \\
\hline & $A L D H 2$ & G1543A & 510 & 388 \\
\hline \multirow[t]{9}{*}{ DNA repair } & hOGGl & Ser326Cys & 269 & 283 \\
\hline & $X R C C 1$ & Arg194Trp & 268 & 285 \\
\hline & & Arg339Gln & 269 & 284 \\
\hline & XRCC3 & Thr241Met & 440 & 276 \\
\hline & ERCC4 & $\mathrm{T} 2505 \mathrm{C}$ & 376 & 335 \\
\hline & ERCC2 & Asp312Asn & 476 & 337 \\
\hline & ATM & $\mathrm{C} 2119 \mathrm{~T}$ & 467 & 332 \\
\hline & $A G T$ & Gly160Arg & 417 & 330 \\
\hline & HER2 & Ile655Val & 505 & 389 \\
\hline \multirow{5}{*}{$\begin{array}{l}\text { Cytokine \& } \\
\text { growth factor }\end{array}$} & $T G F B 1$ & Leu10Pro & 511 & 392 \\
\hline & $T N F B$ & $\mathrm{~A} 252 \mathrm{G}$ & 506 & 387 \\
\hline & $I G F 1$ & G2502 3'UTR & 512 & 389 \\
\hline & $I L-1 B$ & $\mathrm{C}-31 \mathrm{~T}$ & 512 & 394 \\
\hline & $I L I R N$ & 86bp VNTR & 512 & 391 \\
\hline \multirow{8}{*}{$\begin{array}{l}\text { Estrogen } \\
\text { metabolism }\end{array}$} & $E R-\alpha$ & PuvII & 201 & 195 \\
\hline & & XbaI & 201 & 195 \\
\hline & CYPIAI & T6235C & 355 & 210 \\
\hline & & A4889G & 461 & 339 \\
\hline & $C Y P 1 B 1$ & Val432Leu & 268 & 301 \\
\hline & CYP17 & T-1931C 5'UTR & 420 & 322 \\
\hline & СYР19 & Arg264Cys & 379 & 343 \\
\hline & COMT & & & \\
\hline \multirow[t]{2}{*}{ Others } & $B A R 2$ & Gln27Glu & 508 & 389 \\
\hline & MTHFR & C667T & 273 & 266 \\
\hline
\end{tabular}

genotypes.

We conducted a hospital-based case-control study in South Korea to further evaluate the potential modifying role of the genetic polymorphisms of selected genes that are involved in carcinogen metabolisms, estrogen metabolism, signal transduction, and DNA repair. We also took into account the potential interaction between these and the known risk factors of breast cancer (Table 1). The results of the selected genes will be presented in this mini-review.

\section{GSTM1 and T1}

The inherited metabolic capacity of glutathione $S$-transferases (GSTs) have been related to the individual breast cancer risk
(Helzlsouer et al., 1998). GSTs are a superfamily of enzymes that are involved in conjugation with reactive intermediates to soluble glutathione, and therefore, play an important role in the detoxification of endogenous and exogenous toxicants. GSTM1 can detoxify carcinogenic polycyclic aromatic hydrocarbons (PAHs), such as benzo[a]pyrene (BaP) and mycotoxin aflatoxin, while GSTT1 can detoxify smaller reactive hydrocarbons, such as ethylene oxide and diepoxybutane. It can also metabolize solvents. GSTs may also have a role in the metabolism of lipid and DNA products of oxidative stress (Zhu and Conney, 1998). About half of the Asian population lacks GSTM1 and GSTT1 enzyme activities, due to homozygous deletions of the respective genes.

In our study (Park et al., 2000), for the GSTM1 null 
Table 2. Frequency of GSTM1 and GSTT1 genotypes in the study populations

\begin{tabular}{|c|c|c|c|c|c|c|c|c|c|}
\hline & \multicolumn{3}{|c|}{ All women } & \multicolumn{3}{|c|}{ Premenopausal women } & \multicolumn{3}{|c|}{ Postmenopausal women } \\
\hline & $\begin{array}{l}\text { Cases } \\
\mathrm{N}(\%)\end{array}$ & $\begin{array}{l}\text { Controls } \\
\mathrm{N}(\%)\end{array}$ & $\begin{array}{c}\mathrm{OR}^{*} \\
(95 \% \mathrm{CI})\end{array}$ & $\begin{array}{l}\text { Cases } \\
\mathrm{N}(\%)\end{array}$ & $\begin{array}{c}\text { Controls } \\
\mathrm{N}(\%)\end{array}$ & $\begin{array}{c}\mathrm{OR}^{*} \\
(95 \% \mathrm{CI})\end{array}$ & $\begin{array}{l}\text { Cases } \\
\mathrm{N}(\%)\end{array}$ & $\begin{array}{c}\text { Controls } \\
\mathrm{N}(\%)\end{array}$ & $\begin{array}{c}\mathrm{OR}^{*} \\
(95 \% \mathrm{CI})\end{array}$ \\
\hline \multicolumn{10}{|l|}{ GSTM1 } \\
\hline Present & $78(41.5)$ & $86(47.5)$ & 1.0 (ref.) & $43(37.7)$ & $49(50.5)$ & 1.0 (ref.) & $35(47.3)$ & $34(42.5)$ & 1.0 (ref.) \\
\hline Null & $110(58.5)$ & $95(52.5)$ & $1.3(0.84-2.06)$ & $71(62.3)$ & $48(49.5)$ & $2.0(1.05-3.69)$ & $39(52.7)$ & $46(57.5)$ & $0.9(0.45-1.93)$ \\
\hline \multicolumn{10}{|l|}{ GSTT1 } \\
\hline Present & $94(50.0)$ & $105(58.0)$ & 1.0 (ref.) & $57(50.0)$ & $55(56.7)$ & 1.0 (ref.) & $37(50.0)$ & $48(60.0)$ & 1.0 (ref.) \\
\hline Null & $94(50.0)$ & $76(42.0)$ & $1.6(0.98-2.54)$ & $57(50.0)$ & $42(43.3)$ & $1.7(0.94-3.24)$ & $37(50.0)$ & $32(40.0)$ & $1.3(0.64-2.80)$ \\
\hline
\end{tabular}

*OR: odds ratio, 95\% CI : 95\% confidence interval of odds ratio. The ORs were adjusted for age, education, body mass index, age at menarche, age at first pregnancy, age at menopause, smoking, alcohol consumption, duration of breast feeding, family history of breast cancer, and menopausal status at baseline.

Table 3. Association between combined of GST genotypes and breast cancer risk

\begin{tabular}{llll}
\hline & $\begin{array}{l}\text { Cases } \\
\mathrm{N}(\%)\end{array}$ & $\begin{array}{l}\text { Controls } \\
\mathrm{N}(\%)\end{array}$ & $\begin{array}{l}\text { OR } \\
(95 \% \mathrm{CI})\end{array}$ \\
\hline $\begin{array}{l}\text { Combination of GSTMI and GSTT1* } \\
\text { No null }\end{array}$ & $32(17.0)$ & $48(26.5)$ & 1.0 (ref.) \\
One null & $108(57.5)$ & $95(52.5)$ & $1.7(0.98-3.08)$ \\
Both null & $48(25.5)$ & $38(21.0)$ & $2.2(1.13-4.45)$ \\
\hline
\end{tabular}

*Risk of combination of GST genotypes significantly increased by likelihood ratio test to assess linear increase in risk of breast cancer as the number of null genotype increased $(\mathrm{P}$ for trend $=0.02$ ). The ORs were adjusted for education, body mass index, age at menarche, age at first pregnancy, age at menopause, duration of breast feeding, and family history of breast cancer.

genotype, a statistically significant effect was observed among the premenopausal women $(\mathrm{OR}=2.0,95 \% \mathrm{CI}=1.1-3.7)$; whereas, the significant effect of GSTT1 null genotype $(\mathrm{OR}=1.6,95 \% \mathrm{CI}=1.0-2.5)$ in all of the study subjects was mainly attributable to the premenopausal women group $(\mathrm{OR}=1.7,95 \% \mathrm{CI}=0.9-3.2)$ (Table 2$)$. When the potential combined effect of the GSTM1 and GSTT1 genotypes was examined, then the concurrent lack of both of the genes posed more than a two-fold risk of breast cancer $(\mathrm{OR}=2.2,95 \%$ $\mathrm{CI}=1.1-4.5$ ) (Table 3). The most remarkable risk was seen after stratification by the menopausal status at the time of diagnosis; among alcohol-consuming premenopausal women, the concurrent lack of both the GSTMI and GSTT1 genes resulted in more than a five-fold risk of breast cancer $(\mathrm{OR}=5.3,95 \% \mathrm{CI}=1.0-27.8)$ (Table 4$)$.

\section{COMT}

Catechol $O$-methyltransferase (COMT) is one of the key enzymes that are involved in the metabolism of catecholamine in humans. The presumed mechanisms of catechol estrogen in breast carcinogenesis were recently reviewed by Zhu and Conney (1998). Catechol estrogen causes DNA damage either directly, or through its quinone metabolites (Yager and Liehr, 1996). In our study (Yim et al., 2001), the subjects with at least one COMT-L allele had an almost two-fold risk of breast cancer when compared with the COMT-HH genotype individuals ( $\mathrm{OR}=1.7,95 \% \mathrm{CI}=1.04-2.78)$ (Table 5).

\section{ER- $\alpha$}

The estrogen receptor $\alpha(E R-\alpha)$ is an important mediator of the hormonal response in estrogen-sensitive tissues, such as the breast and bones. Therefore, it is conceivable that a variation in the $E R \alpha$ function could affect the proliferation of these tissues. In agreement with this, functional-potentially important polymorphisms in the $E R \alpha$ gene have, although inconsistently, been associated with bone density and breast cancer, as well as endometrial cancer risks. In our recent unpublished study, the PvuII genotype distribution showed no difference between the cases and controls, but the $X b a \mathrm{I} x \mathrm{x}$ genotype posed more than a two-fold risk of breast cancer $(\mathrm{OR}=2.38,95 \% \mathrm{CI}=1.58-3.59)$ when compared with the $\mathrm{X}$ allele that contained genotypes. This increase was mainly attributable to the postmenopausal breast cancer risk $(\mathrm{OR}=$ 3.79, 95\% CI = 1.89-7.62). Combined with XbaI and PvuII, ORs were $2.32(95 \% \mathrm{CI}=1.42-3.81)$ for $\mathrm{xxPP}$ or $\mathrm{xxPp}$ genotype and 2.44 (95\% CI = 1.49-3.99) for xxpp genotype when compared with the genotype that contained the $\mathrm{X}$ allele; their increased risks were statistically significant $(\mathrm{P}$ for trend 
Table 4. Interaction between the combined of GST genotypes and alcohol consumption

\begin{tabular}{|c|c|c|c|c|c|c|}
\hline \multirow[t]{2}{*}{ GST genotypes } & \multicolumn{3}{|c|}{ Never drinker } & \multicolumn{3}{|c|}{ Ever drinker } \\
\hline & $\begin{array}{l}\text { Cases } \\
\mathrm{N}(\%)\end{array}$ & $\begin{array}{c}\text { Controls } \\
\mathrm{N}(\%)\end{array}$ & $\begin{array}{c}\text { OR } \\
(95 \% \mathrm{CI})\end{array}$ & $\begin{array}{l}\text { Cases } \\
\mathrm{N}(\%)\end{array}$ & $\begin{array}{c}\text { Controls } \\
\mathrm{N}(\%)\end{array}$ & $\begin{array}{c}\text { OR } \\
(95 \% \mathrm{CI})\end{array}$ \\
\hline \multicolumn{7}{|l|}{ All women ${ }^{\S}$} \\
\hline No null & $23(16.9)$ & $38(25.5)$ & 1.0 (ref.) & $9(17.3)$ & $10(31.3)$ & 1.0 (ref.) \\
\hline One null & $80(58.8)$ & $77(51.7)$ & $1.7(0.94-3.14)$ & $28(53.8)$ & $18(56.2)$ & $1.7(0.59-5.08)$ \\
\hline Two nulls & $33(24.3)$ & $34(22.8)$ & $1.6(0.79-3.25)$ & $15(28.9)$ & $4(12.5)$ & $4.2(1.01-17.31)$ \\
\hline \multicolumn{7}{|c|}{ Premenopausal women ${ }^{\S}$} \\
\hline No null & $11(14.5)$ & $15(21.1)$ & 1.0 (ref.) & $6(15.8)$ & $8(30.8)$ & 1.0 (ref.) \\
\hline One null & $46(60.5)$ & $43(60.6)$ & $1.5(0.60-3.52)$ & $20(52.6)$ & $15(57.7)$ & $1.8(0.51-6.22)$ \\
\hline Two nulls & $19(25.0)$ & $13(18.3)$ & $2.0(0.70-5.70)$ & $12(31.6)$ & $3(11.5)$ & $5.3(1.03-27.76)$ \\
\hline \multicolumn{7}{|c|}{ Postmenopausal women } \\
\hline No null & $12(20.0)$ & $21(28.4)$ & 1.0 (ref.) & $3(21.4)$ & $2(33.3)$ & 1.0 (ref.) \\
\hline One null & $34(56.7)$ & $33(44.6)$ & $1.8(0.77-4.24)$ & $8(57.2)$ & $3(50.0)$ & $1.8(0.19-16.49)$ \\
\hline Two nulls & $14(23.3)$ & $20(27.0)$ & $1.2(0.46-3.28)$ & $3(21.4)$ & $1(16.7)$ & $2.0(0.11-35.81)$ \\
\hline
\end{tabular}

${ }^{\S} \mathrm{P}$ for trend in ever-drinker $<0.05$

$\mathrm{P}$-value for interaction; $\mathrm{P}=0.02$ for premenopausal women, $\mathrm{P}=0.08$ for postmenopausal women. These $\mathrm{P}$-values for interaction are not changed after adjustment for body mass index.

Table 5. Association between COMT genotypes and development of breast cancer by menopausal status

\begin{tabular}{|c|c|c|c|}
\hline Genotype & Cases N (\%) & Controls N (\%) & OR $(95 \% \mathrm{CI})^{*}$ \\
\hline \multicolumn{4}{|c|}{ All women $($ cases $=163$, controls $=163)$} \\
\hline $\mathrm{HH}$ & $81(50)$ & $101(62)$ & 1.0 (ref.) \\
\hline HL & $79(48)$ & $46(28)$ & $2.3(1.35-3.85)$ \\
\hline LL & $3(2)$ & $16(10)$ & $0.2(0.07-0.92)$ \\
\hline $\mathrm{HH}$ & $81(50)$ & $101(62)$ & 1.0 (ref.) \\
\hline $\mathrm{HL}+\mathrm{LL}$ & $82(50)$ & $62(38)$ & $1.7(1.04-2.78)$ \\
\hline \multicolumn{4}{|c|}{ Postmenopausal women $($ cases $=72$, controls $=72)$} \\
\hline $\mathrm{HH}$ & $34(47)$ & $42(58)$ & 1.0 (ref.) \\
\hline HL & $37(52)$ & $23(32)$ & $2.0(1.00-3.96)$ \\
\hline LL & $1(1)$ & $7(10)$ & $0.2(0.02-1.50)$ \\
\hline $\mathrm{HH}$ & $34(47)$ & $42(58)$ & 1.0 (ref.) \\
\hline $\mathrm{HL}+\mathrm{LL}$ & $38(53)$ & $30(42)$ & $1.6(0.82-3.02)$ \\
\hline \multicolumn{4}{|c|}{ Premenopausal women $($ cases $=91$, controls $=91)$} \\
\hline $\mathrm{HH}$ & $47(52)$ & $59(65)$ & 1.0 (ref.) \\
\hline HL & $42(46)$ & $23(25)$ & $2.3(1.21-4.33)$ \\
\hline LL & $2(2)$ & $9(10)$ & $0.3(0.06-1.35)$ \\
\hline $\mathrm{HH}$ & $47(52)$ & $59(65)$ & 1.0 (ref.) \\
\hline $\mathrm{HL}+\mathrm{LL}$ & $44(48)$ & $32(35)$ & $1.7(0.95-3.13)$ \\
\hline
\end{tabular}

*OR; odds ratio, 95\% CI; 95\% confidence interval of odds ratio. The ORs were adjusted for education, age at menarche, age at first pregnancy, number of live birth baby, duration of breast feeding, smoking, drinking, body mass index and family history of breast cancer.

$<0.001$ ) (Table 7). When the selected tumor phenotypes were considered, then the $\mathrm{C} / \mathrm{G}$ heterozygote posed a 3.5 -fold probability $(95 \% \mathrm{CI}=1.02-11.88)$ and the $\mathrm{G} / \mathrm{G}$ homozygote a 4.7-fold probability (95\% CI $=1.11-19.83)$ of the positive PR expression when compared with the $\mathrm{C} / \mathrm{C}$ homozygote (Table 7) (Kang et al., 2002).

\section{$\mathrm{XRCC1}$}

$\mathrm{XRCC} 1$ is thought to play a role in the multistep base excision repair pathway. There the "non-bulky" base adducts are removed that are produced by methylation, oxidation, reduction, or fragmentation of bases by ionizing radiation or 
Table 6. Frequency of ER $\alpha$ XbaI and PvuII genotypes in the study populations

\begin{tabular}{|c|c|c|c|c|c|c|c|c|c|}
\hline \multirow[b]{2}{*}{ Genotype } & \multicolumn{3}{|l|}{ All women } & \multicolumn{3}{|c|}{ Premenopausal women } & \multicolumn{3}{|c|}{ Postmenopausal women } \\
\hline & $\begin{array}{l}\text { Cases }(\%) \\
(n=201)\end{array}$ & $\begin{array}{l}\text { Controls } \\
(\%) \\
(n=195)\end{array}$ & $\begin{array}{l}\text { Adjusted } \\
\text { OR } \\
(95 \% \text { CI })^{*}\end{array}$ & $\begin{array}{l}\text { Cases }(\%) \\
(\mathrm{n}=122)\end{array}$ & $\begin{array}{l}\text { Controls } \\
(\%) \\
(\mathrm{n}=109)\end{array}$ & $\begin{array}{l}\text { Adjusted } \\
\text { OR } \\
(95 \% \mathrm{CI})^{*}\end{array}$ & $\begin{array}{l}\text { Cases }(\%) \\
(\mathrm{n}=79)\end{array}$ & $\begin{array}{l}\text { Controls } \\
(\%) \\
(\mathrm{n}=81)\end{array}$ & $\begin{array}{l}\text { Adjusted } \\
\text { OR } \\
(95 \% \mathrm{CI})^{*}\end{array}$ \\
\hline \multicolumn{10}{|l|}{ XbaI } \\
\hline XX & $11(5.5)$ & $7(3.6)$ & 1.0 (ref.) & $6(4.9)$ & $3(2.8)$ & 1.0 (ref.) & $5(6.3)$ & $3(3.7)$ & 1.0 (ref.) \\
\hline $\mathrm{Xx}$ & $60(29.8)$ & $102(52.3)$ & $0.4(0.2-1.1)$ & $39(32.0)$ & $54(49.5)$ & $0.4(0.1-1.7)$ & $21(26.6)$ & $46(56.8)$ & $0.2(0.1-0.9)$ \\
\hline $\mathrm{Xx}$ & $130(64.7)$ & $86(44.1)$ & $1.1(0.4-2.9)$ & $77(63.1)$ & $52(47.7)$ & $0.8(0.2-3.4)$ & $53(67.1)$ & $32(39.5)$ & $0.9(0.2-4.3)$ \\
\hline $\mathrm{XX}$ or $\mathrm{Xx}$ & $71(35.3)$ & $109(55.9)$ & 1.0 (ref.) & $45(36.9)$ & $57(52.3)$ & 1.0 (ref.) & $26(32.9)$ & $49(60.5)$ & 1.0 (ref.) \\
\hline $\mathrm{Xx}$ & $130(64.7)$ & $86(44.1)$ & $2.4(1.6-3.6)$ & $77(63.1)$ & $52(47.7)$ & $1.9(1.1-3.2)$ & $53(67.1)$ & $32(39.5)$ & $3.9(1.9-7.8)$ \\
\hline \multicolumn{10}{|l|}{ PvuII } \\
\hline PP & $35(17.4)$ & $26(13.3)$ & 1.0 (ref.) & $21(17.2)$ & $18(16.5)$ & 1.0 (ref.) & $14(17.7)$ & $8(9.9)$ & 1.0 (ref.) \\
\hline $\mathrm{Pp}$ & $91(45.3)$ & $105(53.9)$ & $0.6(0.4-1.2)$ & $56(45.9)$ & $58(53.2)$ & $0.9(0.4-1.8)$ & $35(44.3)$ & $45(55.5)$ & $0.4(0.2-1.2)$ \\
\hline $\mathrm{Pp}$ & $75(37.3)$ & $64(32.8)$ & $0.9(0.5-1.7)$ & $45(36.9)$ & $33(30.3)$ & $1.2(0.6-2.7)$ & $30(38.0)$ & $28(34.6)$ & $0.7(0.2-1.9)$ \\
\hline $\mathrm{PP}$ or $\mathrm{Pp}$ & $126(62.7)$ & $131(67.2)$ & 1.0 (ref.) & $77(63.1)$ & $76(69.7)$ & 1.0 (ref.) & $49(62.0)$ & $53(65.4)$ & 1.0 (ref.) \\
\hline $\mathrm{Pp}$ & $75(37.3)$ & $64(32.8)$ & $1.3(0.8-1.9)$ & $45(36.9)$ & $33(30.3)$ & $1.4(0.8-2.4)$ & $30(38.0)$ & $28(34.6)$ & $1.3(0.7-2.6)$ \\
\hline \multicolumn{10}{|c|}{ Combined genotypes } \\
\hline $\begin{array}{l}\mathrm{X} \text { allele } \\
\text { genotypes } * *\end{array}$ & $71(35.4)$ & $109(55.8)$ & 1.0 (ref.) & $45(36.9)$ & $57(52.2)$ & 1.0 (ref.) & $26(32.9)$ & $49(60.4)$ & 1.0 (ref.) \\
\hline $\mathrm{xxPP} / \mathrm{xxPp}$ & $64(31.8)$ & $43(22.1)$ & $2.4(1.4-3.9)$ & $37(30.3)$ & $26(23.9)$ & $1.8(0.9-3.5)$ & $27(34.2)$ & $16(19.8)$ & $3.8(1.7-8.8)$ \\
\hline Xxpp & $66(32.8)$ & $43(22.1)$ & $2.5(1.5-4.0)$ & $40(32.8)$ & $26(23.9)$ & $1.9(1.0-3.6)$ & $26(32.9)$ & $16(19.8)$ & $3.9(1.7-9.1)$ \\
\hline $\mathrm{P}$ for trend & & & $<0.001$ & & & $<0.05$ & & & $<0.001$ \\
\hline
\end{tabular}

*: Odds ratio were adjusted for age, education level and family history of breast cancer. **: XXPP, XXPp, XXpp, XxPP, XxPx, and Xxpp

Table 7. The association between ER $\alpha$ C975G polymorphism and tumor markers

\begin{tabular}{|c|c|c|c|c|c|}
\hline Genotypes & & Tumor marker number $(\%)$ & & OR $(95 \% \mathrm{CI})$ & $P$ for trend \\
\hline & \multirow{4}{*}{$\begin{array}{c}\mathrm{ER} \\
(\mathrm{n}=89)\end{array}$} & Negative & Positive & & \multirow{4}{*}{0.06} \\
\hline $\mathrm{C} / \mathrm{C}$ & & $10(53)$ & $9(47)$ & 1.0 (ref.) & \\
\hline $\mathrm{C} / \mathrm{G}$ & & $21(40)$ & $31(60)$ & $1.6(0.57-4.72)$ & \\
\hline \multirow[t]{2}{*}{$\mathrm{G} / \mathrm{G}$} & & $4(22)$ & $14(78)$ & $3.9(0.93-16.26)$ & \\
\hline & \multirow{4}{*}{$\begin{array}{c}\mathrm{PR} \\
(\mathrm{n}=89)\end{array}$} & Negative & Positive & & \multirow{4}{*}{0.04} \\
\hline $\mathrm{C} / \mathrm{C}$ & & $15(79)$ & $4(21)$ & 1.0 (ref.) & \\
\hline $\mathrm{C} / \mathrm{G}$ & & $27(52)$ & $25(48)$ & $3.5(1.02-11.88)$ & \\
\hline $\mathrm{G} / \mathrm{G}$ & & $8(44)$ & $10(56)$ & $4.7(1.11-19.83)$ & \\
\hline & \multirow{4}{*}{$\begin{array}{c}\mathrm{p} 53 \\
(\mathrm{n}=88)\end{array}$} & Negative & Positive & & \multirow{4}{*}{0.02} \\
\hline $\mathrm{C} / \mathrm{C}$ & & $8(42)$ & $11(58)$ & 1.0 (ref.) & \\
\hline $\mathrm{C} / \mathrm{G}$ & & $23(45)$ & $28(55)$ & $0.9(0.31-2.57)$ & \\
\hline $\mathrm{G} / \mathrm{G}$ & & $15(83)$ & $3(17)$ & $0.1(0.03-0.68)$ & \\
\hline & \multirow{4}{*}{$\begin{array}{c}c-e r b B 2 \\
(n=88)\end{array}$} & Negative & Positive & & \multirow{4}{*}{0.60} \\
\hline $\mathrm{C} / \mathrm{C}$ & & $10(53)$ & $9(47)$ & 1.0 (ref.) & \\
\hline $\mathrm{C} / \mathrm{G}$ & & $20(39)$ & $31(61)$ & $1.7(0.60-4.80)$ & \\
\hline $\mathrm{G} / \mathrm{G}$ & & $8(44)$ & $10(56)$ & $1.4(0.38-0.68)$ & \\
\hline & \multirow{4}{*}{$\begin{array}{c}\mathrm{bcl}-2 \\
(\mathrm{n}=88)\end{array}$} & Negative & Positive & & \multirow{4}{*}{0.16} \\
\hline $\mathrm{C} / \mathrm{C}$ & & 7 (37) & $12(63)$ & 1.0 (ref.) & \\
\hline $\mathrm{C} / \mathrm{G}$ & & $13(25)$ & $38(75)$ & $1.7(0.55-5.25)$ & \\
\hline $\mathrm{G} / \mathrm{G}$ & & $3(17)$ & $15(83)$ & $2.9(0.62-13.76)$ & \\
\hline
\end{tabular}


Table 8. Association between the $X R C C 1$ genotypes and breast cancer risk

\begin{tabular}{|c|c|c|c|c|c|c|c|c|c|}
\hline & \multicolumn{3}{|c|}{ All women } & \multicolumn{3}{|c|}{ Premenopausal women } & \multicolumn{3}{|c|}{ Postmenopausal women } \\
\hline & $\begin{array}{l}\text { Cases } \\
\mathrm{N}(\%)\end{array}$ & $\begin{array}{c}\text { Controls } \\
\mathrm{N}(\%)\end{array}$ & $\begin{array}{c}\text { OR } \\
(95 \% \mathrm{CI})\end{array}$ & $\begin{array}{l}\text { Cases } \\
\mathrm{N}(\%)\end{array}$ & $\begin{array}{c}\text { Controls } \\
\mathrm{N}(\%)\end{array}$ & $\begin{array}{c}\text { OR } \\
(95 \% \mathrm{CI})\end{array}$ & $\begin{array}{l}\text { Cases } \\
\mathrm{N}(\%)\end{array}$ & $\begin{array}{c}\text { Controls } \\
\mathrm{N}(\%)\end{array}$ & $\begin{array}{c}\text { OR } \\
(95 \% \mathrm{CI})\end{array}$ \\
\hline \multicolumn{10}{|c|}{ XRCC1 codon 194} \\
\hline Arg/Arg & $88(42.9)$ & $92(44.9)$ & 1.0 (ref.) & $54(43.6)$ & $57(49.6)$ & 1.0 (ref.) & $34(42.0)$ & $32(37.6)$ & 1.0 (ref.) \\
\hline Arg/Trp & $94(45.9)$ & $86(41.9)$ & $1.1(0.76-1.73)$ & $54(43.6)$ & $45(39.1)$ & $1.3(0.74-2.18)$ & $40(49.4)$ & $39(45.9)$ & $1.0(0.50-1.86)$ \\
\hline \multirow[t]{2}{*}{ Trp/Trp } & $23(11.2)$ & $27(13.2)$ & $0.9(0.48-1.67)$ & $16(12.8)$ & $13(11.3)$ & $1.3(0.57-2.95)$ & 7 (8.6) & $14(16.5)$ & $0.5(0.17-1.32)$ \\
\hline & & & $\mathrm{P}$ for trend $=1.0$ & & & $\mathrm{P}$ for trend $=0.4$ & & & $P$ for trend $=0.2$ \\
\hline \multicolumn{10}{|c|}{ XRCCl codon 399} \\
\hline Arg/Arg & $92(44.9)$ & $90(43.9)$ & 1.0 (ref.) & $52(41.9)$ & $60(52.2)$ & 1.0 (ref.) & $40(49.4)$ & $28(33.0)$ & 1.0 (ref.) \\
\hline Arg/Gln & $79(38.5)$ & $101(49.3)$ & $0.8(0.51-1.16)$ & $52(41.9)$ & $49(42.6)$ & $1.2(0.72-2.10)$ & $27(33.3)$ & $50(58.8)$ & $0.4(0.19-0.74)$ \\
\hline \multirow[t]{2}{*}{$\mathrm{Gln} / \mathrm{Gln}$} & $34(16.6)$ & $14(6.8)$ & $2.4(1.20-4.72)$ & $20(16.2)$ & $6(5.2)$ & $3.8(1.44-10.30)$ & $14(17.3)$ & $7(8.2)$ & $1.4(0.50-3.91)$ \\
\hline & & & $\mathrm{P}$ for trend $=0.2$ & & & $\mathrm{P}$ for trend $=0.02$ & & & $P$ for trend $=0.5$ \\
\hline
\end{tabular}

The ORs were adjusted for age, education, body mass index, age at menarche, age at first pregnancy, age at menopause, smoking, alcohol consumption, duration of breast feeding, family history of breast cancer, and menopausal status at baseline.

oxidative damage (Yu et al., 1999). Three polymorphisms in the $X R C C 1$ gene have been described, which resulted in Arg194Trp, Arg280His, and Arg399Gln amino acid changes in the XRCC1 protein (Shen et al., 1998). The codon 194 and codon 280 polymorphic sites are located in a linker region that separates the DNA polymerase $\beta$-interacting domain from the PARP-interacting domain. The codon 399 polymorphic site is located in the $\mathrm{COOH}$-terminal side of the PARP-interacting domain, within the BRCT domain, which is homologous to the $\mathrm{COOH}$-terminal region of the breast cancer susceptibility gene $B R C A 1$. Recently, the $X R C C 1$ codon 399 polymorphism has been associated with significant alterations in the DNA repair capacity; whereas, no such data exists for the codon 194 and 280 polymorphisms.

In our recent study (Kim et al., 2002), the XRCCl codon 194 polymorphism did not influence the breast cancer risk; whereas, homozygosity for the codon 399 Gln allele placed women at a 2.4-fold risk (95\% CI $=1.20-4.72)$ for this malignancy; the risk increased to 3.8 -fold $(95 \% \mathrm{CI}=1.44$ 10.30 ) in the premenopausal women. The risk of breast cancer increased with the number of Gln alleles $(\mathrm{P}$ for trend $=0.02)$ (Table 8).

\section{Conclusions}

Breast cancer is the second most frequent cancer in Korean women, and the incidence is increasing in both Western countries and Korea. Although a substantial proportion of breast cancer cases are explained by well-established risk factors (i.e., later age at first pregnancy, nulliparity, and firstdegree family history of breast cancer), the reason for the observed worldwide increase in breast cancer incidences is still largely unknown. The molecular epidemiological approaches using the genetic information in a population- based observational study will provide better mechanistic insights of breast cancer etiology, as well as efficient preventive measures to genetically susceptible population in the future.

\section{References}

Feigelson, H. S. and Henderson, B. E. (1996) Estrogens and breast cancer. Carcinogenesis 17, 2279-2284.

Helzlsouer, K. J., Selmin, O., Huang, H. Y., Strickland, P. T., Hoffman, S., Alberg, A. J., Watson, M., Comstock, G. W. and Bell, D. (1998) Association between glutathione S-transferase M1, P1, and T1 genetic polymorphisms and development of breast cancer. J. Natl. Cancer Inst. 90, 513-518.

Kang, H. J., Kim, S. W., Ahn, S. J., Bae, J. Y., Park, S. K., Kang, D., Hirvonen, A., Choe, K. J. and Noh, D. Y. (2002) Polymorphisms in the estrogen receptor-alpha gene and breast cancer risk. Cancer Lett. 178, 175-180.

Kim, S. U., Park, S. K., Yoo, K. Y., Yoon, K. S., Choi, J. Y., Noh, D. Y., Ahn, S. H., Choe, K. J., Strickland, P. T., Hirvonen, A. and Kang, D. (2002) XRCC1 genetic polymorphism and breast cancer risk. Pharmacogenetics 12, 335-338.

Park, S. K., Yoo, K. Y., Lee, S. J., Kim, S. U., Ahn, S. H., Noh, D. Y., Choe, K. J., Strickland, P. T., Hirvonen, A. and Kang D. (2000) Alcohol consumption, glutathione $S$-transferase M1 and $\mathrm{T} 1$ genetic polymorphisms and breast cancer risk. Pharmacogenetics 10, 1-9.

Parkin, D. M., Whelan, S. L., Ferlay, J., Raymond, L., Young, J. (1997) Cancer Incidence in Five Continents, Vol VII, International Agency for Research on Cancer (IARC). Scientific Publications No. 143, Lyon.

Shen, M. R., Jones, I. M. and Mohrenweiser, H. (1998) Nonconservative amino acid substitution variants exist at polymorphic frequency in DNA genes in healthy humans. Cancer Res. 58, 604-608.

Yager, J. D. and Liehr, J. G. (1996) Molecular mechanisms of estrogen carcinogenesis. Annu. Rev. Pharmacol. Toxicol. 36, 
203-232

Yim, D. S., Park, S. K., Yoo, K. Y., Yoon, K. S., Chung, H. H., Ahn, S. H., Noh, D. Y., Choe, K. J., Jang, I. J., Shin, S. G., Strickland, P. T., Hirvonen, A. and Kang D. (2001) Relationship between the $\mathrm{Val}^{158}$ Met polymorphism of catechol O-methyl transferase and breast cancer. Pharmacogenetics 11, 279-286.

Yoo, K. Y., Kang, D., Park, S. K., Kim, S. U., Shin, A. S., Yoon, H., Ahn, S. H., Noh, D. Y. and Choe, K. J. (2002)
Epidemiology of breast cancer in Korea. Occurrence, high risk groups, and prevention. J. Korean Med. Sci. 17, 386-390

Yu, Z., Chen, J., Ford, B. N., Brackley, M. E. and Glickman, B. W. (1999) Human DNA repair systems: an overview. Environ. Mol. Mutag. 33, 3-20.

Zhu, B. T. and Conney, A. H. (1998) Functional role of estrogen metabolism in target cells; review and perspectives. Carcinogenesis 12, 1-27. 